\title{
A educação no encontro das diferenças: os brasileiros em Portugal
}

\author{
EDUCATION AT THE ENCOUNTER OF DIFFERENCES: BRAZILIANS IN PORTUGAL
}

\author{
https://orcid.org/0000-0003-4111-9238 Juliana Cardoso Ribeiro ${ }^{\mathrm{A}}$ \\ https://orcid.org/0000-0002-5353-3981 João Dantas dos Anjos Neto ${ }^{B}$ \\ iD https://orcid.org/0000-0003-1685-4951 Luis Arthur da Costa Silva ${ }^{\mathrm{C}}$

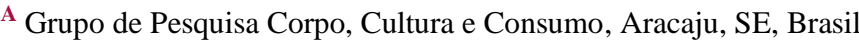 \\ ${ }^{\text {B }}$ Universidade Federal de Goiás (UFG), Goiânia, GO, Brasil \\ ${ }^{\mathrm{C}}$ Facultad Latinoamericana de Ciencias Sociales (FLACSO), Buenos Aires, CABA, Argentina \\ Recebido em: 09 mar. 2021 | Aceito em: 20 ag. 2021 \\ Correspondência: Juliana Cardoso Ribeiro (juliana.aracaju@gmail.com)
}

\section{Resumo}

$\mathrm{O}$ artigo analisa a interferência da variedade linguística entre o português brasileiro e o europeu nas experiências de imigrantes brasileiros em Portugal e qual a importância desse tema na elaboração de políticas de promoção da multiculturalidade, para além das políticas educacionais, naquele país receptor. A variante brasileira do idioma causa um conflito de alteridade que o nacional português traduz em práticas discriminatórias de diferenciação do imigrante brasileiro. Partindo de uma pesquisa exploratória e não probabilística, desdobrada em observação não participante, entrevistas individuais semiestruturadas, grupo focal e análise de conteúdo, conclui-se que o assunto deve constar nas políticas do Estado português de fomento à multiculturalidade e integração de imigrantes.

Palavras-chave: educação; integração; linguagem; migração.

\section{Abstract}

This paper analyzes the interference of the linguistic variety between Brazilian and European Portuguese in the experiences of Brazilian immigrants in Portugal, and the importance of this issue in the elaboration of policies, besides educational ones, that promote multiculturalism in that host country. The Brazilian variant causes a conflict of otherness translated by the Portuguese national into discriminatory practices to differentiate themselves from Brazilian immigrants. Starting from an exploratory and non-probabilistic research, unfolded in nonparticipant observation, individual semi-structured interviews, focus group and content analysis, it is concluded that the subject must be included in the Portuguese State's policies that foment multiculturalism and immigrant integration.

Keywords: education; integration; language; migration. 


\section{Introdução}

Esta pesquisa tem por finalidade discutir em que medida um projeto multicultural para a Educação pode contribuir no combate ao preconceito linguístico sofrido por imigrantes brasileiros em Portugal. Tomando por base uma pesquisa exploratória e não probabilística desenvolvida por Ribeiro (2018) ${ }^{\mathrm{i}}$ quanto à discriminação vivenciada por brasileiros naquele país derivada dos estigmas associados ao seu modo de falar e escrever, buscaremos compreender o papel da Educação na formulação e execução de um contrato social integrador aos imigrantes em questão. Assim, sintetizamos a pergunta de partida dessa investigação na seguinte indagação: Qual a relevância de se analisar as experiências de imigrantes brasileiros em Portugal, no que tange à sua relação com a variedade linguística, para a concepção de políticas que promovam a multiculturalidade nessa sociedade de acolhimento, para além do espaço escolar e acadêmico?

Destarte, na esfera educacional, o compromisso com a difusão da língua portuguesa foi assumido pelos Estados-membros da Comunidade dos Países de Língua Portuguesa empregando-se uma perspectiva de valorização da pluralidade de relações com o idioma, a saber, por meio da proteção e promoção da diversidade linguística dos países lusófonos, incluindo-se nessas políticas as línguas maternas, a língua de sinais, as línguas de migração e as variedades dialetais do português. (CPLP, 2016, p. 25).

Em entrevista recente, o ministro dos Negócios Estrangeiros de Portugal, Augusto Santos Silva, enalteceu a importância de se consolidar o aprendizado do português como idioma de acolhimento de imigrantes não lusófonos, pois a integração bem sucedida de imigrantes em Portugal como os provenientes de países da África ou do Leste Europeu estaria vinculada a esse aprendizado. Na sua visão, os imigrantes de nações lusófonas estariam em vantagem com relação aos demais, posto que, neste caso, “[...] a língua não é uma barreira, pelo contrário, é um traço de união.” (ONU NEWS, 2020, on-line). Tal observação está em consonância com o Plano Estratégico para as Migrações, elaborado pelo Estado português, no qual se reconhecem as "[...] históricas relações culturais e afinidades linguísticas [...]” com alguns dos países emissores de imigrantes que buscam estabilidade política e social e, portanto, melhores condições de vida em Portugal (DIÁRIO DA REPÚBLICA, 2015, p. 1654-(3)).

Seja qual for a razão (política, econômica, familiar ou outra), quem chega precisa de agir linguisticamente de forma autônoma, num contexto que não lhe é familiar. Raramente alguém deixa o seu espaço de afetos se não tiver uma forte motivação que passa muitas vezes pela própria sobrevivência e pela melhoria das condições de vida [...] (GROSSO, 2010, p. 66). 
No tocante ao Brasil, trata-se do país cujos nacionais compõem, atualmente, a maior comunidade de expatriados em Portugal. Segundo dados do Serviço de Estrangeiros e Fronteiras (SEF) deste país, a comunidade brasileira possui 151.304 integrantes, o que representa 25,6\% do total de 590.348 estrangeiros titulares de autorização de residência em Portugal (SEF, 2019, p. 16). De acordo com Padilla (2010), a diáspora de brasileiros para Portugal cresce, pelo menos, desde 1960, quando essa comunidade correspondia, oficialmente, a 6.357 imigrantes, passando a 9.962 em 1981, 13.499 em 1991 e 31.869 em 2001. Os laços históricos entre ambos os países, que remontam ao período colonial, converteram-se em políticas atrativas para imigrantes brasileiros, relativas aos processos de legalização, ao estatuto de igualdade quanto aos direitos políticos e aos acordos de reciprocidade em matéria, por exemplo, de seguridade social e assistência consular (PADILLA, 2010, p. 90-109).

A investigação de Ribeiro (2018), no entanto, revela-nos que, embora o vínculo idiomático igualmente pese na decisão de brasileiros de emigrar para Portugal, a adaptação no país receptor não acontece de modo linear, já que “[...] a diferença de sotaques e expressões acaba por causar certos dissabores, especialmente no início do processo migratório." (RIBEIRO, 2018, p. 109). A partir do estudo de Bem (2005), depreende-se que a língua, num mundo pós-colonial entrecruzado por fluxos migratórios internacionais, é instrumentalizada em prol da “[ ...] legitimação discursiva da exclusão de imigrantes [...]", servindo de "[...] pretexto para o desenvolvimento de políticas assimilacionistas [...]” que visam à “[...] estigmatização dos imigrantes como culturalmente inflexíveis e inadaptáveis.” (BEM, 2005, p. 44). Isso ocorre porque, conforme explica Santos (2019) em sua análise sobre glotofobia, “[...] a língua que falamos e o modo como a falamos [...]" descortina, ao outro, aspectos pessoais em termos socioculturais, étnicos e históricos, de maneira que “[...] o ato de elocução que deveria ser afirmação de si próprio pode transformar-se numa forma de denúncia, de não pertença ao grupo dominante." (SANTOS, 2019, p. 2).

Assim, o preconceito linguístico surge, essencialmente, ao nível da fala e não da escrita, considerando que esta última é aprendida a partir do ensino formal, enquanto a fala é adquirida por qualquer ser humano, de forma natural, bastando para isso o contacto com outros falantes de um dado idioma. $\mathrm{O}$ preconceito linguístico está associado ao preconceito socioeconómico e cultural, sendo a linguagem "fonte tanto de assimilação quanto de exclusão". (FERNANDES, 2013, p. 25).

Boneu (2003) argumenta que a discriminação de cariz linguístico é prejudicial tanto aos imigrantes, como à própria nação de acolhimento. Ainda que os imigrantes procedam de países economicamente desfavorecidos ou de zonas de conflito, os níveis macroeconômicos do país 
receptor tendem a crescer com a sua presença, o que justifica abrir-lhes as portas (BONEU, 2003, p. 181-182). Logo, segundo caracteriza a Organização Internacional para as Migrações (OIM), o preconceito linguístico é uma forma de xenofobia, pois as condutas que derivam desse tipo de discriminação possuem o intuito subjacente, ou nem tanto, de anular ou prejudicar o reconhecimento, o gozo e o exercício igualitário de direitos e liberdades por todas as pessoas, ao rejeitar, excluir e estigmatizar segmentos (OIM, 2019, p. 54-235) com base na intersecção entre a sua origem, os seus traços fenotípicos e a sua forma de comunicar-se oralmente e/ou por escrito.

O imigrante sob o jugo do preconceito é visto pela parte discriminadora como uma categoria humana que condensa os estereótipos relacionados à sua nacionalidade, isto é, uma identidade desprovida de nuanças, um clichê (BEM, 2005, p. 52). A sua integração à sociedade receptora nunca se completa, a sua cidadania jamais é plena já que cada manifestação de discriminação e/ou preconceito, inclusive linguístico, serve para questionar o seu "[...] sentido de merecimento de inclusão e pertencimento." (BARTLETT; RODRÍGUEZ; OLIVEIRA, 2015, p. 1167). Integrar é uma via de mão dupla, pois requer do país de acolhimento a incorporação do imigrante à sua vida social, cultural, política e econômica, devendo o imigrante, por sua vez, adaptar-se à uma série de responsabilidades particulares e comunitárias tanto no âmbito da inclusão social, como da coesão social (OIM, 2019, p. 106). O processo de integração, portanto, é:

[...] complexo e interativo, com múltiplas facetas, que envolve o desenvolvimento de interdependências entre uma diversidade de atores, agentes e territórios [...] resultante da interação entre fatores estruturais na sociedade de acolhimento (oportunidades e processos de partilha) e comportamentos dos imigrantes (características culturais, capacidade de iniciativa e expectativas face à sociedade de acolhimento). (HORTAS, 2013, p. 37).

O estudo desenvolvido por Ribeiro (2018) enriquece esse debate, ao constatar que os sujeitos entrevistados relatavam espontaneamente que a variação linguística entre Brasil e Portugal trazia-lhes obstáculos em distintas etapas do seus percursos migratórios, principalmente no início das suas experiências no país receptor, "[...] na medida em que os sujeitos nativos da sociedade portuguesa e os indivíduos desta comunidade de imigrantes possuem formas diferentes de interpretar os sinais de uma linguagem.” (RIBEIRO, 2018, p. 153-155). 
A fim de superar as adversidades linguísticas, a prática educativa possui o papel primordial de considerar que o "[...] construto língua-cultura [...]" carrega consigo um arcabouço de significados, experiências e componentes socioculturais relevantes, para além da aprendizagem do "[...] conhecimento linguístico estrutural de uma língua [...]”. (BARBOSA; SÃO BERNARDO, 2017, p. 60). Tais elementos serão analisados em profundidade na seção subsequente, de modo inter-relacionado com as respostas obtidas por Ribeiro (2018) através dos métodos elencados abaixo:

a) Pesquisa exploratória, efetuada via observação não participante em sete locais (bares, igrejas e o Bairro das Fontainhas) frequentados por brasileiros no Distrito do Porto, em Portugal. Em três, constatou-se uma frequência maior de brasileiros em relação aos demais territórios visitados. Ao todo, foram concluídas dezenove observações, realizadas entre os dias 01 de março de 2015 e 14 de junho de 2015;

b) Entrevistas individuais e semiestruturadas conduzidas com vinte brasileiros residentes em Portugal, sendo dez do sexo masculino e dez do sexo feminino, entre os dias 30 de março de 2015 e 28 de julho de 2015. No dia 20 de setembro de 2016, realizou-se uma entrevista a mais, posto que o perfil sociológico do(a) entrevistado(a) possuía relevância para o objeto da pesquisa;

c) Grupo focal, que reuniu um grupo de quatro brasileiros num primeiro encontro. Os integrantes foram selecionados deliberadamente entre os entrevistados, com vistas a aprofundar a descoberta de opiniões concernentes aos assuntos de interesse da pesquisa. O grupo focal foi descontinuado já no segundo encontro devido à dificuldade de reunir os participantes;

d) Análise de conteúdo categorial das entrevistas, executada após as etapas metodológicas anteriores, com o fito de produzir inferências que permitissem captar os significados implícitos no material recolhido. Foram utilizadas cinco categorias de análise: Ambiente sociodemográfico dos sujeitos; Condições dos sujeitos e condição de regularidade; Integração dos brasileiros à sociedade portuguesa; Particularidades da integração de brasileiros face à variedade do português Brasileiro e Europeu; Percepções dos brasileiros sobre o preconceito e a discriminação na sociedade portuguesa. (RIBEIRO, 2018, p. 118-124). 
Em seguida, nas considerações finais, uma revisão bibliográfica encaminhará a discussão acerca da importância da Educação para frear e reverter a discriminação e o preconceito de ordem linguística que afeta esses imigrantes.

\title{
A encruzilhada sociolinguística dos imigrantes brasileiros em Portugal
}

A identidade linguística entre Portugal e Brasil teve início no processo de colonização dos territórios localizados na América do Sul. Um dos principais elementos dessa ocupação foi a educação jesuíta: apoiada pela monarquia portuguesa, disseminou a língua portuguesa a fim de catequizar os povos originários. Paiva (2015) sustenta que:

\begin{abstract}
"Aprendendo a língua, tornaram-se intérpretes e, mais do que isso, ignoraram as diferentes culturas indígenas e empreenderam o recolhimento de crianças, o aldeamento de adultos e a utilização de uma língua geral com vistas a suprimir a visão de mundo dos selvagens e, assim, poder ensinar a nova cultura. [...] a presença dos inacianos foi tão significativa e seu domínio tão vasto que nenhuma outra ordem se lançou à mesma tarefa, e a Coroa não conseguiu preencher a lacuna deixada por eles, embora seu inimigo declarado, o Marquês de Pombal (1699-1782), tenha intentado fazê-lo." (PAIVA, 2015, p. 206).
\end{abstract}

Paralelamente à missão jesuíta, os setores administrativos responsáveis pela produção de documentos e pelos registros da época colonial, assim como o meio artístico e intelectual (em virtude da literatura escrita em idioma português naquele período) e os campos econômicos e políticos (em razão do processo de escravização) contribuíram para o sucesso da lusofonia como signo político colonial (SEVERO, 2016, p. 1324). Este fato ocorreu de forma casual, e não premeditada (LOURENÇO, 2001 apud SEVERO, 2016, p. 1324). O laço linguístico com Portugal nunca se rompeu.

Embora apontada por imigrantes brasileiros como um fator de escolha de Portugal como país de residência, esta identidade linguística não necessariamente facilita o processo migratório. O fato é que este processo é atravessado por constrangimentos e perturbações causados por variações de sotaques, de sentido, divergência no significado de palavras e de interpretação da escrita e de significados de maneiras de expressão, os quais podem interferir na integração dos brasileiros em Portugal, não obstante a suposta afinidade quanto ao idioma.

No decorrer da pesquisa de campo, estas questões foram apontadas inicialmente e de forma espontânea como algumas dificuldades iniciais de integração sentidas por quatro entrevistados, os quais relataram impasses de entendimento relativos ao léxico (diferença de palavras), à semântica (significado de palavras), à velocidade da fala, à forma de expressão e à escrita. Salienta-se que todos os indivíduos que relataram atribulações face às questões linguísticas também noticiaram a dirimição rápida destas questões. Contudo, entendemos que 
o relato espontâneo destas lembranças pode significar que tais vicissitudes tiveram grande relevância no processo de chegada desses indivíduos a Portugal.

A análise reservada a pesquisa relativa à integração de imigrantes brasileiros, no que diz respeito à questão da língua(gem), foi debruçada mais especificamente sobre a categoria de análise denominada Particularidades da integração de brasileiros face à variedade do português brasileiro e europeu. Nesta categoria, incluíram-se as subcategorias denominadas Dificuldades iniciais de integração em razão da variação linguística entre Brasil e Portugal, Tentativa de absorção do sotaque do português de Portugal e, por fim, Preconceitos elou discriminações face à variação linguística. Neste artigo, daremos mais atenção às situações de preconceitos e discriminações apresentadas durante a coleta de dados tanto das entrevistas, como do grupo focal. Importa ressaltar que cada indivíduo possui uma leitura diferente sobre o que é ou não situação de preconceito e/ou discriminação, de forma que em situações similares, aquilo que é representado como preconceito e/ou discriminação para um sujeito, pode não o ser para outro, a depender da percepção individual de cada um.

Onze entrevistados entenderam não haver preconceito face à variação linguística. Alguns, inclusive, enfatizaram a reação positiva de muitos nacionais portugueses em relação à pronúncia brasileira, que caracterizam como "macia" e "suave", tal como se exemplifica na fala de uma das entrevistadas:

Não. Muito pelo contrário. Eles até gostam. E às vezes ficam me perguntando: Por que você fala português? E eu digo: Porque gosto. Mas a maioria das pessoas gostam porque dizem que a gente fala cantando, porque é uma voz muito macia, muito suave. Nunca senti nenhum tipo de preconceito em relação a isso. (BR_F_11, 42 anos, 8 anos de imigração).

Destaca-se, neste caso, a ideia de "brasilidade" representada na pronúncia "suave" da variante do português brasileiro: seu "valor adocicado" estaria pautado na economia açucareira do Brasil colônia, tendo sido popularizado por meio das obras literárias de autores brasileiros. Tais autores qualificaram a língua brasileira como "doce", baseados no entendimento de Gilberto Freyre - o qual caracterizou o colonizador português no Brasil por sua doçura no tratamento do escravo, sendo a docilidade da variante brasileira do português vista como uma consequência deste tratamento de um colonizador mais flexível e que tinha sido influenciado pelos Mouros (SEVERO, 2015, p. 90-95; FREYRE, 2003 apud SEVERO, 2015, p. 91-94; FREYRE, 2003, p. 285; DEBBANÉ, 1911 apud FREYRE, 2003, p. 298).

A miscigenação das raças como um traço característico de engrenagem colonial teria deslizado para as línguas. A natureza adocicada, amolecida, deliciosa, dengosa, servil e suave, valores que são transpostos para a língua falada no Brasil e que a distinguiram 
do português da metrópole, seriam efeitos das relações entre um colonizador mais adaptável, solidário, protetor e tolerante com escravizados submissos e servis. (SEVERO, 2015, p. 95).

Este valor simbólico atribuído à variedade brasileira do português, que se baseia na docilidade e miscigenação de raças, coloca-o em uma posição inferior ao português falado em Portugal. Durante o trabalho de campo, observamos que a incorporação desta docilidade na língua é utilizada por muitos brasileiros em busca de aceitação na sociedade portuguesa. Esta prática pode ser exemplificada por meio do comentário de um dos entrevistados, o qual confirma o emprego dessa variedade como meio de barganha em um jogo de sedução. $\mathrm{O}$ entrevistado, assim, nega a existência de preconceito e/ou discriminação relativa à utilização por brasileiros da variedade do português do Brasil em Portugal:

\begin{abstract}
Não, não. Discriminação nenhuma. Pelo contrário. Me ajudou muito. Me ajudou muito, muito, muito. Principalmente com as portuguesas, na altura. Porque eu era solteiro e ajudava muito. Sempre gostava... Ouvia a gente a falar, sabe? De maneira que a gente gostava de ouvir elas falando. Eu ficava sempre assim... (BR_M_9, 39 anos, cerca de 16 a 17 anos de imigração).
\end{abstract}

Contudo, não se pode generalizar que o sotaque brasileiro causa incômodos ao conjunto da população de Portugal. O entrevistado BR_M_1, por exemplo, relatou que a sua esposa, de nacionalidade portuguesa e que sempre morou em Portugal, teria absorvido a pronúncia da variedade brasileira do português, apenas motivada pelo gosto que possui por sua sonoridade.

Outro entrevistado, por sua vez, enaltece a fonética brasileira, mas a vê como uma língua estrangeira:

Ontem mesmo, eu tava trabalhando com um miúdo, tem 16 anos. 'Então cara! Tudo bem! tal, tal'. E eu... 'Aí tal tal..' Eu falei: 'Ouve lá! Você tá a brincar com a minha cara? O que é que é?' 'Não. É que eu gosto muito de falar brasileiro'. 'Olha! Você tá sendo um estúpido. Teu pai e tua mãe não te ensinou, não? O brasileiro não fala português, nós falamos estrangeiro'. 'Não. Mas é o sotaque de vocês... É mais bonito, mais gostoso'. Eles gostam do nosso sotaque [...] (BR_M_3, 55 anos, 35 anos de imigração).

A desvalorização da variedade do português brasileiro pelo próprio brasileiro pode ser encarada como resultante de um processo de violência simbólica caracterizada pela aceitação da definição dominante da sua identidade, estabelecida por um entendimento existente em Portugal de que o brasileiro não fala português. Bagno (2007), ao esclarecer o mito de que "Brasileiro não sabe português" / "Só em Portugal se fala bem português", critica esta percepção, lendo-a como uma postura preconceituosa e relacionada ao subdesenvolvimento do Brasil, tendo em vista a visão de que a população brasileira seria uma mistura negativa de raças 
em que o negro e o índio ocupariam uma posição inferior ao branco na pirâmide populacional. Assim, por não constituírem uma raça pura, tampouco se conceberia a existência de uma língua pura (BAGNO, 2007, p. 21). A representação transcrita abaixo traz outro exemplo de uma situação de preconceito linguístico e mostra claramente o olhar vertical de um nacional português sobre a variedade do português falado e escrito por nossa entrevistada brasileira:

[Risos] A amiga minha de trabalho. Querendo ensinar eu a falar português correto. E outras também. 'Ai, brasileira, não é assim que diz'. 'Tu está em Portugal. Tu tem é que aprender a falar o português daqui, o sotaque daqui'. Eu falei assim: 'Mas eu, nessa idade, aprendi a falar a língua de lá. E vou continuar falando. É português, só que com palavras diferente'. O sotaque é diferente. (BR_F_21, 36 anos, 10 anos de imigração).

Alguns sujeitos brasileiros, apesar de não perceberem a existência de preconceito relativo à variedade brasileira do português, descrevem circunstâncias em que nacionais portugueses desdenham da fala e da escrita de brasileiros, que estariam enquadradas nas situações de preconceito linguístico defendidas por Bagno (2007, p. 21-22). Referidos relatos, demonstram a ideia arraigada na mentalidade portuguesa de que o brasileiro não fala e não escreve bem o português. Estas circunstâncias nem sempre são percebidas pelos imigrantes brasileiros, que as veem como normais ou como alguma espécie de "brincadeira":

Não, não senti assim... Não sen/ Não senti, assim, nenhum preconceito. Bom, as pessoas às vezes gozam, falam, brincam, mas... são coisas também que não.. Eu também gozo com eles, às vezes. Mas num... Mas tem... Mas tem pessoas que, às vezes, gozam, né? da... da forma da gen/ dos brasileiros falarem, né? Acham que a gente não fala bem certas coisas. A gente fala mal. Mas pronto. Mas... Mas já vi pessoas fazer isso. São coisas também que eu não... Passa ao lado, [como muitos] [risos]. (BR_M_1, 44 anos, 23 anos de imigração).

Também não. Eles falam que nós escrevemos... Assim... Que o brasileiro escreve o português errado, que eles que ensinaram o português pro brasileiro. Que o brasileiro escreve o português errado, fala errado, que não sei o quê. Mas isso, eu levo como... na brincadeira... O que eles falam. (BR_M_10, 42 anos, quase 5 anos de imigração).

Outras vezes, o preconceito culmina em uma assimilação do sujeito imigrante, o qual não possui alternativa a não ser enquadrar-se a um cenário de violência simbólica:

\footnotetext{
Âh... Eu tenho... algumas amigas portuguesas que corrigem-me sempre. Mas eu... eu apanho isso como um... como um crescimento. Falar melhor. Às vezes, que eu tenho mesmo/como eu estou cá a viver, tenho que... mesmo me adaptar... aqui. Não é? Então, algumas coisas eu falo errado e... tenho/ Eles (que) corrigem. 'Ah! Tu tem que falar assim, assado, que é o português correto' Eu prefiro me adaptar do que enfrentar. Não vou ganhar nada com isso, não é? Melhor a gente fazer as coisas certas. (BR_F_19, 38 anos, 5 anos de imigração).
}

Os corpos subalternizados, não na sua totalidade, invisibilizam para si os processos de opressão, subjugação e estigmatização, ora como reação psíquica de defesa, por não suportar a 
dor em fazer contato com o seu lugar social, ora pela sua própria docilização. Ou, conforme Bourdieu (2001):

Exposto ao mundo, à sensação, ao sentimento, ao sofrimento etc., ou seja, envolvido no mundo, como caução e móvel de disputa no mundo, o corpo (bem) disposto em relação ao mundo está orientado, em igual medida, para o mundo e ao que aí se presta imediatamente a ver, a sentir e a pressentir; ele é capaz de dominá-lo trazendo-lhe uma resposta adaptada, de ter controle sobre ele, de utiliza-lo (e não de decifrá-lo) como um instrumento que se tem nas mãos (segundo a célebre analise de Heidegger) e o qual, jamais considerado como tal, e perpassado, como se fosse transparente, pela tarefa que ele permite cumprir e pela qual ele se orienta. (BOURDIEU, 2001, p. 174).

O teórico cultural e sociólogo jamaicano Stuart Hall (1997) enfatiza que a linguagem utilizada no processo de representação depende dos significados conceituais existentes nas mentes dos sujeitos, que derivam da relação das coisas que existem no mundo e do sistema dos conceitos e imagens que são formados nos pensamentos. Ressalta-se, ainda, que as pessoas que pertencem às diferentes culturas possuem mapas conceituais divergentes e diferentes formas de interpretação de linguagem (HALL, 1997, p. 17-19). Sob outro prisma, a negação da existência desse preconceito pode também estar relacionada com a falta do desejo do sujeito em reconhecê-lo, uma vez que este reconhecimento representaria o fato de que ele, de certa forma, não teria sido aceito pela sociedade portuguesa. Esta interpretação reforça o nosso entendimento de que cada indivíduo desenvolve estratégias, através de discursos e práticas, que o conduzem durante o seu processo de integração à sociedade portuguesa e que estão pautadas em experiências individuais de mundo vivenciadas desde o seu nascimento até a travessia migratória.

Diante de situações similares às expostas acima, outra parte dos entrevistados faz uma leitura negativa de algumas tentativas de reprodução da pronúncia brasileira pelos portugueses, vendo esta atitude como preconceituosa e diferenciando-se das demais representações dos brasileiros. Nesse sentido, foram relatadas situações cotidianas em ambientes diversificados, incluindo o ambiente acadêmico, em que portugueses tentavam imitar a sonoridade e a maneira de falar do brasileiro, tal como demonstrado nos fragmentos a seguir:

Sim, já já.. Já vi algumas vezes, sim. O sotaque que a gente fala é:: por exemplo, eles... Eles tentam imitar a gente, não é, falando: Olha! Eu não tenho trocadinho, não é? Eu não trocad/ 'Não tenho trocadínho', não é? Certo? Tentando imitar de uma forma pejorativa. Acho que sim. Isso é uma forma de preconceito. (BR_M_5, 58 anos, 8 anos de imigração).

Porque eu tô te falando, até na faculdade eles ficavam me zuando e tentando me imitar e zuando do meu sotaque. Lógico! Querendo curtir com a minha 
cara, e eu colocava eles no lugar deles. (BR_F_13, 38 anos, 15 anos de imigração).

Lembro, porque uma vez eu saí com meu marido... E no Brasil, a gente costuma falar as redondas, que tem assim: a gente fala queijim. No Brasil, a gente fala queijim. Aquele queijim, aquele queijim. Então, são palavras que aqui muda. Certo? E a maneira da gente falar. Porque eu sou do norte. PoRta. E a gente leva um tempo pra perder esse sotaque. E mesmo assim, ainda carrega o sotaque. Então, muitos vezes, eles riam da gente a falar. E muitas vezes, eu falo: "Tá rindo de quê, palhaço?". (BR_F_17, 38 anos, 6 anos de imigração).

Houve, ainda, dois relatos espontâneos de situações de preconceito linguístico colocados e coletados previamente à inquirição das questões sobre as consequências das variações linguísticas. O entrevistado BR_M_5 menciona sobre a não aceitação da variedade do português brasileiro pelo nacional português. Já a entrevistada BR_F_12 relatou quanto à existência de preconceito e discriminação na faculdade onde estudava e quando tentou preencher uma vaga para o cargo de educadora de infância. Trata-se de uma discriminação que culminou na não aceitação da entrevistada para o cargo em razão da sua pronúncia:

Por causa do sotaque. Por exemplo, eu não consigo emprego em uma escola privada. Eu fiz uma entrevista em uma escola muito conceituada do Porto, que por uma questão de ética não vou dizer o nome, e fiquei selecionada. Eu e uma menina de 23 anos, recém licenciada, sem experiência alguma. (...) Pronto, fiquei sentada, conversa vai, conversa vem. A diretora da escola disse: Olha BR_F_12! Nós adoramos o teu currículo, amei a tua entrevista. A tua experiência com as crianças aqui foi maravilhosa, mas se tu não tivesse esse sotaquezinho brasileiro, o emprego era teu. (BR_F_12, 46 anos, 7 anos de imigração, alto nível de habilitação académica na área da educação, Educadora de Infância).

Apesar da sua vasta experiência na área do ensino infantil, a entrevistada viu-se preterida em prol de uma outra candidata inexperiente, apenas pelo fato de possuir uma "pronúncia não desejada" naquela instituição de ensino. Esta atitude demonstra claramente, o prejuízo que a discriminação linguística em relação a variedade brasileira do português pode causar para um imigrante brasileiro em Portugal. Neste mesmo sentido, a entrevistada BR_F_19, ao ser questionada sobre as dificuldades iniciais encontradas em Portugal, relata contrariedades que podem acontecer quando o brasileiro almeja a aquisição de um trabalho na sociedade portuguesa, e esclarece que muito embora os empregadores não se importem com a nacionalidade na área do subemprego, quando há uma procura por trabalho relacionado com a escrita, por exemplo, em escritórios, ter a nacionalidade brasileira pode influenciar negativamente para a aquisição deste emprego, por uma questão relacionada ao domínio da variedade do português europeu. Segue o excerto da sua fala: 
É porque se for no subemprego/é por isso que eu perguntei em qual sentido. Porque no subemprego, ser brasileira é... eles não olham a sua nacionalidade. Mas quando é na sua profissão, quando é uma coisa... um escritório, alguma coisa assim, eles demandam por causa da redação, algumas coisas para escrever e-mail, responder e-mail. E isso é importante. Saber fazer o dialeto daqui, não é? (BR_F_19, 38 anos, 5 anos de imigração).

No grupo focal, a entrevistada BR_F_12 relatou as dificuldades que encontrou no meio acadêmico descrevendo a situação em que a sua orientadora lhe solicitou mudanças na redação da sua tese por considerá-la "abrasileirada":

Mas também teve outras dificuldades. Por exemplo, na universidade, quando eu fui escrever minha tese, eu tinha uma colega francesa, uma espanhola, um Erasmus que veio de Cabo Verde, outra veio de Moçambique, e de outros países. E na hora de escrever a minha tese, a minha professora e orientadora disse: BR_F_12, tô lendo esta tua tese aqui, tá muito abrasileirada'. Eu disse: "Mas tem que tá. Eu nasci no Brasil, escrevo no Brasil, tem que tá abrasileirada". (BR_F_12, durante a realização do grupo focal).

Assim, após o estudo do material coletado, observamos que, por um lado, o valor simbólico adocicado da variedade brasileira do português é convertido por imigrantes brasileiros numa técnica para se sentirem mais integrados à sociedade portuguesa; por outro, o preconceito e a discriminação linguística são bastantes presentes em vários setores da sociedade portuguesa, inclusive no contexto escolar/acadêmico. Ainda que não sejam sempre percebidos pelos brasileiros, esses problemas podem influenciar no seu processo de integração em Portugal, tanto na sua vida social, como nos demais contextos do uso cotidiano da língua em sua forma oral e escrita - este último caso é agravado no ambiente acadêmico e nos empregos onde a escrita é um meio necessário.

Isto posto, é importante termos em conta a proposição de Biderman (2001) que consta na sua pesquisa a respeito da identidade e dos contrastes entre o português falado no Brasil e o falado em Portugal: a língua portuguesa, tanto em Portugal como no Brasil, é essencialmente a mesma, e ambas as variedades possuem identidades de estruturas e oposições funcionais, diferenciando-se apenas em suas normas (BIDERMAN, 2001, p. 966) - embora haja acordos ortográficos entre os dois países, como o firmado em 1990, em vigor desde 2009. De acordo com a Declaração Constitutiva da CPLP, a língua portuguesa: "É um meio privilegiado de difusão da criação cultural entre os povos que falam português e de projeção internacional dos seus valores culturais, numa perspectiva aberta e universalista" (CPLP, 1996). Além disso, a CPLP considera que o idioma português: "Constitui, entre os respectivos povos, um vínculo histórico e um património comum, resultante de uma convivência multissecular que deve ser 
valorizada" (CPLP, 1996). Logo, a utilização de todas as variedades da língua portuguesa deve ser valorizada e naturalizada.

\section{Considerações Finais}

Esta investigação perscrutou os caminhos que se interseccionam no encontro sociolinguístico entre imigrantes brasileiros e nacionais portugueses. Com o objetivo de responder à pergunta de partida, revisitamos o estudo qualitativo, exploratório e não probabilístico conduzido por RIBEIRO (2018), no qual identificaram-se as dificuldades, recusas e hostilidades que orbitam os imigrantes brasileiros em Portugal.

A discriminação e o preconceito de caráter linguístico se revelam dentro e fora das instituições em geral. Como demonstrado através do tratamento dos dados coletados, condutas discriminatórias relacionadas às distinções entre o português do Brasil e o de Portugal podem obstaculizar o acesso de profissionais brasileiros a empregos no campo educacional no país de acolhimento. No entanto, as entrevistas também denotam que o alcance da discriminação e do preconceito linguístico transborda o meio institucional, pois possui raízes histórico-culturais e perpetua-se na sociedade portuguesa através de violências simbólicas até mesmo sutis, muitas vezes imperceptíveis aos imigrantes brasileiros.

Alguns entrevistados contaram não se sentir discriminados diante de manifestações de preconceito linguístico por parte de nacionais portugueses. Recorrendo a Lacan (1995), é possível ponderar que esta negação pode representar um método de sobrevivência na nação receptora: um negacionismo velado que esconde os reais afetos vinculados ao objeto (LACAN, 1995, p. 93). Desse modo, depreende-se que as políticas de enfrentamento à discriminação e ao preconceito não só precisam considerar a vertente linguística da xenofobia, como o fato de que ela se apresenta, em múltiplas ocasiões, diluída em discursos, gestos e práticas passíveis até de parecer positivos sob a ótica dos imigrantes brasileiros.

Apesar de não se tratar de uma pesquisa no âmbito do Estruturalismo, a sincronicidade entre os métodos científicos empregados possibilitou uma espécie de bricolagem, no sentido de ver, sentir e reestruturar determinados fatos do mundo. Assim, foi possível contemplar o objeto numa perspectiva simultaneamente sócio-histórica, antropológica, educacional e psicológica, descobrindo elementos que evidenciam um conflito da alteridade no cerne do preconceito linguístico.

Desde a chegada dos primeiros colonizadores ao que hoje entendemos por Brasil, o repertório mítico dos povos originários colidiu com o idioma, a cosmovisão e o projeto colonial 
dos portugueses. O imigrante brasileiro atual, que faz a travessia inversa à dos colonizadores, cumpre o papel de outro, servindo para reafirmar a identidade cultural do nacional português que nasceu e reside na metrópole. Portanto, este se sente compelido a erigir uma nova hierarquia que subjugue aquele outro através de violências simbólicas que reforcem o seu poder sobre o imigrante brasileiro. Traçando um paralelo com Han (2019), é uma escolha previsível, pois "para os deuses, a violência é um método evidente, natural para alcançar seus objetivos e sua vontade própria" (HAN, 2019, p. 18).

A investigação, ao dialogar com a pergunta de partida, permite concluir que a discriminação e o preconceito linguístico devem ser combatidos no âmbito de políticas de promoção da multiculturalidade dentro e fora dos ambientes escolares/acadêmicos. Importa que essa problemática se insira no contexto das políticas migratórias e educacionais do Estado português, de modo que abranja desde o planejamento curricular, para torná-lo mais inclusivo à variação brasileira da língua portuguesa, até a elaboração de ações específicas para a integração laboral (e em outros segmentos) dos imigrantes brasileiros na sociedade de acolhimento.

\section{Referências}

BAGNO, M. Preconceito linguístico: o que é e como se faz. São Paulo: Edições Loyola, 2007.

BARBOSA, L. M. de A.; SÃO BERNARDO, M. A. A importância da língua na integração dos/as haitianos/as no Brasil. Périplos: Revista de Pesquisa sobre Migrações, Brasília, v. 1, n. 1, p. 58-67, 2017. Disponível em: http://www.repositorio.ufc.br/handle/riufc/51205. Acesso em: 22 fev. 2021.

BARTLETT, L.; RODRÍGUEZ, D.; OLIVEIRA, G. Migração e educação: perspectivas socioculturais. Educação e Pesquisa, São Paulo, v. 41, n. especial, p. 1153-1171, dez., 2015. Disponível em: https://doi.org/10.1590/S1517-9702201508144891. Acesso em: 22 fev. 2021.

BEM, A. S. A dialética do turismo sexual. Campinas: Papirus, 2005.

BIDERMAN, M. T. C. O português brasileiro e o português europeu: identidade e contrastes. Revue belge de philologie e d'histoire, Bélgica, v. 79, n. 3, p. 963-975, 2001. Disponível em: https://doi.org/10.3406/rbph.2001.4556. Acesso em: 18 fev. 2021.

BONEU, M. S. Promover la diversidad. In: RIBEIRO, M. M. T. (Coord.). Europa em mutação - Cidadania. Identidades. Diversidade Cultural. Coimbra: Quarteto Editora, 2003. P. 175-199.

BOURDIEU, P. Meditações pascalianas. Rio de Janeiro: Editora Bertrand Brasil S.A., 2001. 
COMUNIDADE DOS PAÍSES DE LÍNGUA PORTUGUESA (CPLP). Declaração

Constitutiva da Comunidade dos Países de Língua Portuguesa. Lisboa, 1996, 3p.

COMUNIDADE DOS PAÍSES DE LÍNGUA PORTUGUESA (CPLP). Plano de Ação de Cooperação Multilateral no Domínio da Educação da CPLP (2016-2020). Díli, 2016, 25p.

COSTA, W. S. Na procura do país irmão, o encontro com o primo distante. Significados atribuídos à experiência de imigração por mulheres brasileiras no Distrito do Porto. 199f. Tese, Doutoramento em Psicologia Social, Instituto de Educação e Psicologia da Universidade do Minho, Braga, 2009.

FERNANDES, A. N. O preconceito cultural e linguístico na escola portuguesa. 189f. Dissertação, Mestrado em Português Língua Não Materna, Departamento de Humanidades da Universidade Aberta, Lisboa, 2013.

FREYRE, G. Casa-grande \& Senzala: formação da família brasileira sob o regime da economia patriarcal. Recife: Global Editora, 2003.

GROSSO, M. J. R. Língua de acolhimento, língua de integração. Revista Horizontes de Linguística Aplicada, v. 9, n. 2, p. 61-77, 2010. Disponível em:

https://periodicos.unb.br/index.php/horizontesla/article/view/886/771. Acesso em: $21 \mathrm{fev}$. 2021.

HALL, S. The work of representation. In: HALL, Stuart (Org.). Representation: cultural representations and cultural signifying practices. London/Thousand Oaks/New Delhi: SAGE Publications; The Open University, 1997. P. 13-74.

HAN, B.-C. Topologia da violência. Petrópolis: Vozes, 2019.

HORTAS, M. J. Educação e imigração: a integração dos alunos imigrantes nas escolas do ensino básico do centro histórico de Lisboa. Lisboa: Alto Comissariado para a Imigração e Diálogo Intercultural, 2013. Disponível em:

https://www.om.acm.gov.pt/documents/58428/177157/ESTUDO+50.pdf/6530c8a9-b43f4bf5-99e4-678312b1c994. Acesso em: 19 fev. 2021.

LACAN, J. O Seminário, livro 4: a relação de objeto. Rio de Janeiro: Jorge Zahar, 1995.

MACHADO, I. J. R. Apontamentos para uma etnografia da imigração brasileira no Porto, Portugal. In: A questão social no novo milénio, 2004, Centro de Estudos Sociais da Universidade de Coimbra, Actas do VIII Congresso Luso-Africano-Brasileiro de Ciências Sociais. Coimbra: 2004a, p. 1-23. Disponível em: https://www.ces.uc.pt/lab2004/pdfs/IgorMachado.pdf. Acesso em: 22 fev. 2021.

MACHADO, I. J. R., Cárcere público: processos de exotização entre imigrantes brasileiros no Porto, Portugal. 320f. Tese, Doutorado em Ciências Sociais, Departamento de Sociologia do Instituto de Filosofia e Ciências Humanas da Universidade Estadual de Campinas, Campinas, 2003. 
MACHADO, I. J. R. Imigrantes brasileiros no Porto: aproximação à perenidade de ordens raciais e coloniais portuguesas. Lusotopie, Aix-en-Provence, n. 11, p. 121-140, 2004b.

Disponível em: https://www.persee.fr/doc/luso_1257-0273_2004_num_11_1_1593. Acesso em: 18 fev. 2021.

MALHEIROS, J. M.; ESTEVES, A. Diagnóstico da população imigrante em Portugal: desafios e potencialidades. Lisboa: Alto-Comissariado para a Imigração e Diálogo Intercultural, 2013. Disponível em: http://hdl.handle.net/10451/38904. Acesso em: 18 fev. 2021.

MORAES, A. C. R. Geografia histórica do Brasil: capitalismo, território e periferia. São Paulo: Annablume, 2011.

ORGANIZAÇÃO INTERNACIONAL PARA AS MIGRAÇÕES (OIM). Glossary on migration. Genebra, 2019, 235p. Disponível em:

https://publications.iom.int/system/files/pdf/iml_34_glossary.pdf. Acesso em: 18 fev. 2021.

PADILLA, B. Migraciones transatlánticas y globalización: brasileños en tierras lusas y el poder de las redes sociales. América Latina Hoy, Salamanca, v. 55, p. 85-114, sep., 2010. Disponível em: https://doi.org/10.14201/alh.7264. Acesso em: 22 fev. 2021.

PAIVA, W. A. O legado dos jesuítas na educação brasileira. Educação em Revista, Belo Horizonte, v. 31, n. 4, p. 201-222, out./dez., 2015. Disponível em: https://doi.org/10.1590/0102-4698136933. Acesso em: 18 fev. 2021.

PORTUGAL investe no ensino da língua portuguesa para integrar migrantes. ONU News, 9 out. 2020, Migrantes e Refugiados. Disponível em:

https://news.un.org/pt/story/2020/10/1728612. Acesso em: 19 fev. 2021.

REPÚBLICA PORTUGUESA. Plano Estratégico para Migrações (PEM, 2015-2020). Diário da República, Portugal, $1^{\text {a }}$ série, n. 56, p. 1654-(2-24), mar. 2015. Disponível em: http://www.dge.mec.pt/sites/default/files/ECidadania/Educacao_Intercultural/documentos/pla no_estrategico_migracoes_2015-2020.pdf. Acesso em: 20 fev. 2021.

RIBEIRO, J. C. As trilhas depois da chegada: Desafios alusivos às diferenciações linguísticas, aos estereótipos lançados e à etnicidade no processo de integração de Brasileiros e Cabo-verdianos no Porto. 302f. Tese, Doutoramento em Sociologia, Departamento de Sociologia, Instituto de Sociologia da Faculdade de Letras da Universidade do Porto, Porto, 2018.

SANTOS, G. Glotofobia: da discriminação linguística ao racismo pelo sotaque. Memoirs Newsletter, Coimbra, n. 60, p. 1-3, jul. 2019. Disponível em:

https://memoirs.ces.uc.pt/ficheiros/4_RESULTS_AND_IMPACT/4.3_NEWSLETTER/MEM OIRS_newsletter_60_GS_pt.pdf. Acesso em: 18 fev. 2021.

SERVIÇO DE ESTRANGEIROS E FRONTEIRAS (Portugal). Relatório de Imigração, Fronteiras e Asilo. Oeiras, 2019, 90p. Disponível em: https://sefstat.sef.pt/Docs/Rifa2019.pdf. Acesso em: 22 fev. 2021. 
SEVERO, C. G. A açucarada língua portuguesa: lusotropicalismo e lusofonia no século XXI. Revista Brasileira de Linguística Aplicada, Belo Horizonte, v. 15, n. 1, p. 85-107, jan./mar., 2015. Disponível em: https://doi.org/10.1590/1984-639820155522. Acesso em: 20 fev. 2021.

SEVERO, C. G. Lusofonia, colonialismo e globalização. Fórum Linguístico, Florianópolis, v. 13, n. 3, p. 1321-1333, jul./set., 2016. Disponível em: https://doi.org/10.5007/19848412.2016v13n3p1321. Acesso em: 20 fev. 2021.

${ }^{\text {i }}$ Pesquisa conduzida pela Dra. Juliana Cardoso Ribeiro no âmbito na sua tese de Doutoramento em Sociologia pela Universidade do Porto, defendida e aprovada em fevereiro de 2018, sob orientação da Dra. Helena Carlota Ribeiro Vilaça (Universidade do Porto) e coorientação da Dra. Isabel Estrada Carvalhais (Universidade do Minho), e intitulada: "As trilhas depois da chegada: Desafios alusivos às diferenciações linguísticas, aos estereótipos lançados e à etnicidade no processo de integração de Brasileiros e Cabo-verdianos no Porto". 